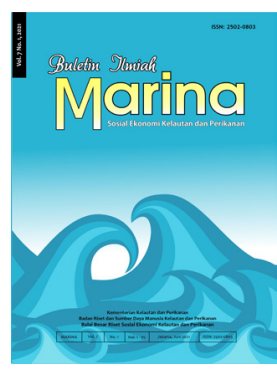

BULETIN ILMIAH MARINA

SOSIAL EKONOMI KELAUTAN DAN PERIKANAN

http://ejournal-balitbang.kkp.go.id/index.php/mra

p-ISSN: 2502-0803

e-ISSN: 2541-2930

Nomor Akreditasi: 10/E/KPT/2019

\title{
Karakterisasi Pelaku Usaha Patin untuk Mendukung Jambi sebagai Sentra Patin Nasional
}

\section{Characterization of Patin Business Actors to support Jambi as the National Patin Center}

\author{
*Putinur, Randi B. S. Salampessy, dan Achmad Poernomo \\ Politeknik Ahli Usaha Perikanan \\ JIn. Raya Pasar Minggu, Jakarta Selatan, DKI Jakarta, Indonesia \\ Diterima tanggal: 26 Maret 2020 Diterima setelah perbaikan: 19 Mei 2021 \\ Disetujui terbit: 30 Juni 2021
}

\begin{abstract}
ABSTRAK
Ikan patin merupakan salah satu komoditas unggulan yang ditetapkan oleh Kementerian Kelautan dan Perikanan (KKP) dalam program percepatan industrialisasi perikanan budi daya. KKP terus melakukan pemantauan dan mendorong produksi patin nasional dengan mendirikan sentra patin di beberapa provinsi, salah satunya Provinsi Jambi. Mengingat adanya potensi pengembangan budi daya patin yang besar, sejak 2017 Provinsi Jambi dicanangkan menjadi sentra ikan nasional, tetapi hingga saat ini belum terealisasi. Penelitian ini bertujuan memberikan gambaran terkini kondisi perikanan patin di Provinsi Jambi. Penelitian dilaksanakan pada bulan Februari hingga Agustus 2019 menggunakan metode deskriptif, dengan pendekatan studi kasus. Proses pengambilan data dilakukan dengan observasi dan wawancara terhadap key informan. Responden dalam penelitian ini adalah pelaku usaha yang ditentukan dengan Metode Slovin, responden konsumen serta pembuat kebijakan yang ditentukan dengan purposive sampling. Kondisi industri budi daya terkini menunjukkan bahwa pembudi daya mengalami beberapa permasalahan, diantaranya: keterbatasan modal, serangan penyakit, sulitnya memperoleh bahan baku pembuatan pakan mandiri serta masalah utama terbatasnya akses pemasaran, sedangkan pada industri pengolahan terlihat banyaknya jumlah unit pengolahan yang tidak beroperasional baik skala UMKM maupun skala besar seperti UPI fillet patin, serta permasalahan umum terbatasnya akses pemasaran. Berdasarkan permasalahan di atas, penunjukan Provinsi Jambi sebagai sentra patin nasional belum berhasil, maka rekomendasi yang dapat diusulkan yaitu menjadikan program sentra patin nasional sebagai salah satu agenda di RPJMD atau Renstra DKP Provinsi Jambi, pemerintah merevitalisasi kembali unit pengolahan fillet patin, membuka jaringan pemasaran yang lebih luas, menyediakan penampung tetap hasil panen, serta perlu adanya penyediaan informasi penyedia bahan baku untuk pembuatan pakan mandiri.
\end{abstract}

Kata Kunci: budi daya; ikan patin; industri; pengolahan; Provinsi Jambi

\begin{abstract}
Pangasius has become one of the largest commodities in the acceleration program of aquaculture industry of the Ministry of Marine Affairs and Fisheries (MMAF). In order to constantly monitor and encourage the production of national pangasius, MMAF has established pangasius centers in several provinces, one of them is located in Jambi Province. Considering the large potential for developing pangasius aquaculture, since 2017 Jambi was proclaimed as a national fish center, but it has not been realized. The research aimed to describe a current picture of the condition of pangasius fisheries in Jambi Province. The research was conducted from February to August 2019 by using descriptive method with case study approach. Data were collected by observation and depth interview to key informan. Respondents of the research were businessmen were determined by Slovin method, consumers, and policy makers were determined by purposive sampling. The aquaculture industry exhibits several problems including: limited business capital, disease attack, difficult obtain of
\end{abstract}


raw materials for independent feed, as well as the main problem in limited access of its marketing, meanwhile In processing industry, there are a large number of idle processing units, both small scale processing units and large-scale processing units such as Fish Processing Unit (UPI) of Pangasius Fillet and common problems in marketing access. Based on above issues, the appointment of Jambi Province as a national pangasius center has not been successful. Therefore, it is recommended to enclose the national pangasius center program in the Regional Mid-Term Development Plan (RPJMD) or marine and fisheries strategic plan of Jambi Province, to revive the catfish fillet processing unit, to expand the wide-ranging access of marketing, to facilitate the harvested catfish in permanent container, and to provide information of raw material supplier for independent food production.

Keywords: aquaculture; pangasius; industry; processing; Jambi Province

\section{PENDAHULUAN}

\section{Latar Belakang}

Dalam rangka program percepatan industrialisasi perikanan budi daya, Kementerian Kelautan dan Perikanan (KKP) menetapkan beberapa komoditas unggulan, salah satunya ikan patin. Peluang ekspor ikan patin cukup besar di pasar internasional, demikian juga di pasar domestik, dengan kondisi kegemaran masyarakat mengkonsumsi ikan patin yang sangat tinggi (Susanti et al., 2017). Menurut Asmaida et al. (2019), ikan patin sangat diminati oleh konsumen karena sehat untuk dikonsumsi, mengandung nilai gizi yang baik untuk kesehatan, rasanya enak, mudah dalam pengolahannya, mudah didapatkan, tingkat kesegarannya tinggi, dan harga yang relatif murah.

Peluang industrialisasi patin saat ini terbuka luas sejak adanya kebijakan larangan impor patin yang dikeluarkan oleh KKP. Berdasarkan data sejak tahun 2014, Indonesia sudah tidak menerima pasokan ikan patin impor. Selain itu, tingginya syarat keamanan pangan yang ditetapkan KKP melalui Standar Nasional Indonesia (SNI) menjadi peluang bagi patin lokal untuk menguasai pasar (Sari, 2018). Adanya kebijakan proteksi impor patin, industri patin Indonesia menunjukkan adanya perkembangan. Hal ini terlihat dari meningkatnya produksi patin nasional yang terdiri dari budi daya kolam, keramba, jaring apung, jaring tancap, dan minapadi pada tahun 2017 sebanyak 319.966 ton, naik 22,25\% menjadi 391.151 ton pada tahun 2018 (Direktorat Jenderal Perikanan Budidaya [DJPB], 2019). Sentra produksi patin di Indonesia telah tersedia, dalam hal ini KKP melakukan pemantauan dan mendorong produksi patin nasional. Wilayah Sumatra menyumbang $68,07 \%$ dari produksi nasional, yang meliputi Sumatra Selatan, Jambi, Riau, dan Lampung.
Provinsi Jambi merupakan salah satu daerah yang menjadi sentra pengembangan komoditas ikan patin di Indonesia. Produksi patin di Provinsi Jambi mencapai 19.511 ton pada tahun 2016, sebanyak 21.631,30 ton pada tahun 2017 dan meningkat menjadi 24.856,60 ton pada tahun 2019 (Dinas Kelautan dan Perikanan [DKP] Provinsi Jambi, 2020). Komoditas patin di Provinsi Jambi menjadi produksi perikanan budi daya terbesar jika dibandingkan dengan komoditas budi daya lainnya sehingga Provinsi Jambi dinilai memiliki potensi besar untuk digarap sebagai sentra budi daya patin nasional. Mengingat adanya potensi pengembangan budi daya ikan patin yang besar, sejak tahun 2017, Provinsi Jambi dicanangkan menjadi lumbung ikan nasional, tetapi hingga saat ini penetapan Provinsi Jambi sebagai salah satu sentra ikan nasional belum terealisasi sehingga perlu dikaji secara komprehensif. Penelitian ini bertujuan memberikan gambaran mengenai kondisi terkini perikanan patin di Provinsi Jambi dengan studi kasus di Kabupaten Muaro Jambi.

\section{Pendekatan IImiah}

Penelitian dilakukan pada bulan Februari hingga Agustus 2019 bertempat di Provinsi Jambi, dengan studi kasus di Kabupaten Muaro Jambi. Pengumpulan data dan informasi dilakukan dengan wawancara mendalam terhadap responden yang telah ditentukan dengan menggunakan kuesioner serta melakukan observasi langsung pada lokasi pembudi daya ikan patin, unit pengolahan ikan patin, serta pasar yang menjual ikan patin.

Data yang dikumpulkan dari kegiatan wawancara bertujuan untuk memperoleh keterangan secara lisan melalui percakapan dan tatap muka dengan orang yang diwawancarai yang mempunyai kepakaran di bidang budi daya maupun pengolahan ikan patin. Di samping itu, kegiatan pengumpulan data dan informasi melalui observasi 
dilakukan dengan cara mengamati kondisi lokasi penelitian, seperti aktivitas budi daya, aktivitas pengolahan ikan patin, aktivitas pemasaran, serta sosial ekonomi masyarakat di sekitar kawasan budi daya. Observasi penting dilakukan agar penelitian dapat menemukan hal-hal yang tidak terungkap dalam wawancara dan kuesioner, serta penting untuk melakukan cross -check terhadap jawaban key informant yang berkaitan dengan objek penelitian.

Responden yang terlibat dalam penelitian terdiri atas tiga kelompok, yaitu 1) Pembudi daya dan pengolah ikan patin selaku pelaku usaha; 2) Pedagang dan ibu rumah tangga selaku konsumen; serta 3) Dinas Kelautan dan Perikanan selaku pembuat kebijakan. Penentuan responden pelaku usaha pembudi daya ikan patin dilakukan dengan menggunakan rumus Taro Yamane (Metode Slovin) dengan responden terpilih berjumlah 57 orang, sedangkan responden pengolah ikan patin berjumlah 2 orang dengan pertimbangan unit pengolahan tersebut aktif melaksanakan proses produksi. Responden konsumen berjumlah 15 orang dipilih secara purposive sampling dengan ketentuan bahwa yang bersangkutan terlibat dalam kegiatan industri perikanan patin dan bersedia untuk diwawancarai.

Analisis deskriptif digunakan untuk menggambarkan kondisi faktual perikanan patin di Kabupaten Muaro Jambi yang dikelompokkan ke dalam tujuh elemen, yaitu karakteristik responden pembudi daya, karakteristik responden pengolah dan usaha pengolahan ikan patin, profil usaha budi daya, aspek kelembagaan, aspek teknologi, aspek pemasaran, permasalahan dan kendala serta harapan pelaku usaha ikan patin.

\section{KARAKTERISTIK RESPONDEN PEMBUDI DAYA PATIN}

Karakteristik responden pembudi daya patin berdasarkan jenis kelamin, umur, pendidikan, dan lama usaha. Berikut analisis terhadap hasil isian kuesioner yang digunakan dan disebarkan kepada pembudi daya patin yang terpilih menjadi responden dalam penelitian ini:

\section{1) Jenis kelamin}

Kegiatan budi daya ikan patin telah berkembang lama di Kabupaten Muaro Jambi dan secara turun-temurun sudah menjadi mata pencaharian utama bagi sebagian besar masyarakat, di samping perkebunan dan pertanian. Jenis kelamin para pembudi daya patin di
Kabupaten Muaro Jambi didominasi oleh laki-laki, yakni $86 \%$, sedangkan $14 \%$ kegiatan budi daya lainnya dilakukan oleh perempuan (Tabel 1).

Tabel 1. Karakteristik Responden Pembudi Daya Berdasarkan Jenis Kelamin.

\begin{tabular}{lcc}
\hline Jenis Kelamin & Jumlah (Orang) & Persentase (\%) \\
\hline Laki-laki & 49 & 86 \\
Perempuan & 8 & 14 \\
\hline Total & $\mathbf{5 7}$ & $\mathbf{1 0 0}$ \\
\hline Sumber: Data Primer Diolah, 2019 &
\end{tabular}

Berdasarkan data pada Tabel 1 terlihat bahwa kegiatan budi daya tidak hanya dilakukan oleh kaum laki-laki, tetapi juga dilakukan oleh kaum perempuan. Perbedaan jenis kelamin tidak menjadi penghalang bagi kaum perempuan untuk melakukan kegiatan budi daya yang umumnya dilakukan oleh kaum laki-laki. Hal ini sejalan dengan penelitian yang dilakukan oleh Asmaida dan Rogayah (2020) terhadap pembudi daya perempuan di Kabupaten Muaro Jambi yang menyebutkan bahwa para pembudi daya tersebut masih produktif dan memiliki pengalaman di budi daya patin selama rata-rata 14 tahun. Perkembangan di bidang ekonomi dan teknologi mengakibatkan partisipasi tenaga kerja wanita di bidang budi daya mulai meningkat. Kesadaran perempuan tentang kesetaraan gender menjadi wadah bagi perempuan untuk mengembangkan potensi yang ada pada dirinya sehingga perempuan dapat mandiri dan ikut berpartisipasi dalam pembangunan, khususnya di sektor perikanan.

2) Umur

Umurpembudi dayaikan patin yang dimaksud dalam penelitian ini adalah usia pembudi daya ikan patin sejak lahir hingga penelitian ini dilakukan yang dinyatakan dalam tahun. Berdasarkan pengelompokan umur yang dilakukan, mayoritas responden pembudi daya memiliki kategori umur muda, yaitu berkisar antara 24-35 tahun dengan persentase $42 \%$ (Tabel 2).

Tabel 2. Karakteristik Responden Pembudi Daya Berdasarkan Umur.

\begin{tabular}{lcc}
\hline Umur (Tahun) & $\begin{array}{c}\text { Jumlah } \\
\text { (Orang) }\end{array}$ & Persentase (\%) \\
\hline Muda (24-35) & 24 & 42 \\
Sedang (36-45) & 18 & 32 \\
Tua (>46) & 15 & 26 \\
\hline Total & $\mathbf{5 7}$ & $\mathbf{1 0 0}$ \\
\hline
\end{tabular}

Sumber: Data Primer Diolah, 2019 
Banyaknya jumlah pembudi daya dengan rentang umur muda mempunyai pengaruh dalam kegiatan budi daya. Pembudi daya dengan umur muda cenderung memiliki semangat dan minat yang tinggi untuk mengetahui hal baru serta mempermudah dalam transfer teknologi maupun informasi. Menurut Aprolita (2008), umur merupakan salah satu faktor yang diperkirakan dapat menentukan kemampuan atau kekuatan seorang pembudi daya dalam berperilaku mandiri supaya tercapai suatu keberhasilan dalam usaha budi dayanya, dalam mencari nafkah atau melakukan aktivitas budi daya.

3) Pendidikan

Dari 57 orang responden pembudi daya, sebagian besar memiliki tingkat pendidikan sedang (SLTP sederajat dan SLTA sederajat) dengan persentase $61 \%$ (Tabel 3).

Tabel 3. Karakteristik Pembudi Daya Responden Berdasarkan Pendidikan.

\begin{tabular}{lcc}
\hline Jenjang Pendidikan & $\begin{array}{c}\text { Jumlah } \\
\text { (Orang) }\end{array}$ & $\begin{array}{c}\text { Persentase } \\
\text { (\%) }\end{array}$ \\
\hline Rendah (SD) & 14 & 25 \\
Sedang (SLTP dan SLTA) & 35 & 61 \\
Tinggi (Perguruan Tinggi) & 8 & 14 \\
\hline Total & $\mathbf{5 7}$ & $\mathbf{1 0 0}$ \\
\hline
\end{tabular}

Sumber: Data Primer Diolah, 2019

Hasil penelitian yang diperoleh sama seperti yang dilakukan oleh Aprolita (2008) yang menunjukkan bahwa tingkat pendidikan pembudi daya patin berada dalam kategori sedang dengan persentase $39,1 \%$. Kualifikasi tingkat pendidikan menunjukkan kemampuan seorang pelaku dalam menangkap informasi teknologi yang cenderung dinamis. Gambaran tingkat pendidikan juga digunakan untuk melihat sejauh mana akses pendidikan yang telah mampu dijangkau dengan baik oleh pelaku usaha budi daya ikan patin di Kabupaten Muaro Jambi.

Menurut Rumimpunu et al. (2017), adanya perbedaan tingkat pendidikan dapat mempengaruhi produktivitas kerja yang berdampak langsung terhadap peningkatan produk akuakultur, sehingga diperlukan upaya lain selain pendidikan formal untuk menambah pengetahuan dan wawasan dari pembudi daya terkait dengan kegiatan budi daya.

\section{4) Pengalaman Usaha}

Mayoritas pengalaman usaha responden pembudi daya dalam menjalankan usaha adalah berkisar antara 5-8 tahun sebanyak 22 orang (39\%), lebih dari 9 tahun sebanyak 18 orang (32\%), sedangkan lainnya berkisar $1-4$ tahun sebanyak 17 orang (29\%). Hasil penelitian yang dilakukan oleh Aprolita (2008) menunjukkan bahwa sebagian besar pembudi daya sudah cukup lama dalam melakukan usaha budi daya ikan patin, yaitu berkisar 4-10 tahun.

Semakin lama usaha dijalankan, maka semakin banyak pula pengalaman serta pengetahuan yang diperoleh. Pengalaman memicu semangat untuk belajar dan memperbesar usaha, seperti menambah jumlah kolam, meningkatkan hasil produksi maupun menambah jenis komoditi lain yang dibudidayakan. Tingkat pengalaman usaha dapat mempengaruhi efektivitas proses produksi budi daya sehingga berdampak pada keberlanjutan usaha yang dikelola serta menjadi tolak ukur untuk pengembangan usaha di masa yang akan datang. Menurut Cocon (2018), pengalaman usaha di bidang budi daya menjadi tolak ukur seberapa jauh pelaku budi daya mampu menguasai manajemen, baik teknis maupun nonteknis dalam pengelolaan akuakultur serta menunjukkan kapasitas sumber daya manusia pelaku usaha tersebut.

\section{KARAKTERISTIK RESPONDEN PENGOLAH DAN USAHA PENGOLAHAN IKAN}

Istilah pengolah diperuntukkan bagi setiap orang yang bermata pencaharian melakukan usaha pengolahan ikan (Keputusan Menteri Kelautan dan Perikanan Nomor 14 Tahun 2012). Pengolahan hasil perikanan menjadi penting dengan pertimbangan, antara lain, meningkatkan nilai tambah, kualitas hasil, penyerapan tenaga kerja, keterampilan produsen, dan pendapatan produsen.

Kondisi unit pengolahan ikan di Kabupaten Muaro Jambi saat ini masih terbatas. Terbentuknya unit pengolahan di kabupaten ini dikarenakan adanya surplus produksi atau terjadinya produksi berlebih dari kelompok pembudi daya. Unit Pengolahan Ikan (UPI) yang ada di Kabupaten Muaro Jambi masih dalam skala mikro kecil menengah (UMKM) dan 1 unit pengolahan skala besar (UPI fillet patin). Kondisi saat ini menunjukkan bahwa hanya ada 2 unit pengolahan skala UMKM yang masih aktif beroperasi. Karakteristik responden pengolah dapat dilihat pada Tabel 4. Jenis produk yang dihasilkan oleh responden pengolah adalah: 
1. UMKM Tunas Baru, memproduksi abon ikan dan kerupuk tulang ikan;

2. UMKM Indri Jaya, memproduksi stick ikan.

Tabel 4. Karakteristik Responden Pengolah.

\begin{tabular}{lccc}
\hline Nama UMKM & Umur & Pendidikan & $\begin{array}{c}\text { Lama } \\
\text { Usaha }\end{array}$ \\
\hline Tunas Baru & $\begin{array}{c}46 \text { tahun } \\
\text { 36-45 } \\
\text { Indri Jaya }\end{array}$ & SLTA & 13 tahun \\
\hline
\end{tabular}

Sumber: Data Primer Diolah, 2019

Bahan baku yang digunakan dalam kegiatan produksi berasal dari kolam milik pribadi dan pembudi daya yang ada di sekitar lokasi unit pengolahan. Ketersediaan bahan baku untuk kedua unit pengolahan ini terpenuhi dan mudah memperolehnya. Burhan (2004) menyatakan bahwa ketersediaan bahan baku yang memenuhi kapasitas serta kontinu dapat mempengaruhi kelancaran kegiatan produksi. Lokasi kedua unit pengolahan sangat strategis dilihat dari sumber bahan baku, dikarenakan Kecamatan Kumpeh Ulu dan Kecamatan Sungai Gelam merupakan 2 (dua) kecamatan yang memproduksi patin terbesar di Muaro Jambi. Jarak antara sumber bahan baku dengan lokasi unit pengolahan \pm 1 kilometer. Kebutuhan bahan baku ikan patin dalam sekali produksi untuk pengolahan di UMKM Tunas Baru adalah 200-250 kg, sedangkan UMKM Indri Jaya membutuhkan bahan baku sebanyak $15-30 \mathrm{~kg}$.

Lokasi unit pengolahan berdampingan dengan rumah tempat tinggal, tetapi terdapat ruangan khusus untuk melakukan proses pengolahan yang telah disediakan oleh pemilik unit pengolahan, dekat dengan sumber air, tersedianya sumber daya manusia (SDM) yang bertempat tinggal tidak jauh dari lokasi unit pengolahan serta jauh dari tempat pembuangan atau penampungan sampah dan daerah peternakan. Sumber pasokan air untuk proses pengolahan berasal dari air PAM dan air sumur bor.

Kegiatan produksi di UMKM Tunas Baru dilakukan sebanyak dua kali dalam satu minggu, sedangkan UMKM Indri Jaya sebanyak satu kali dalam satu minggu. Permintaan produk abon, kerupuk tulang ikan patin, dan stick ikan patin meningkat, yakni di bulan puasa, hari besar atau hari raya, serta permintaan abon patin juga ada dari pemerintah untuk bekal jamaah haji dari Provinsi Jambi.
UMKM Tunas Baru menyerap tenaga kerja sebanyak 12 orang dan UMKM Indri Jaya sebanyak 3 orang yang merupakan ibu rumah tangga dan penduduk di sekitar unit pengolahan dengan rata-rata usia berkisar antara $30-45$ tahun. Tingkat pendidikan tenaga kerja paling rendah adalah SD dan paling tinggi adalah SLTA sederajat. Waktu kerja karyawan dalam sehari adalah \pm 8 jam.

Pengolahan produk di dua UMKM tersebut menerapkan nir-limbah (zero waste concept) sehingga proses pengolahan bahan baku ikan terpakai seluruhnya. Proses pembuatan abon dan stick ikan hanya menggunakan ikan patin bagian dagingnya saja, bagian kulit ikan digunakan dalam pembuatan kerupuk kulit, sedangkan sisa tulang dan kepala diolah lebih lanjut menjadi kerupuk tulang ikan. Limbah isi perut ikan sisa pengolahan dimanfaatkan untuk pakan ternak dan juga pakan ikan patin yang ada di kolam budi daya. Keberlanjutan usaha pengolahan sebagai unit bisnis tidak bisa terlepas dari perubahan kondisi ekonomi, minat, dan selera konsumen sehingga suatu unit pengolahan diharapkan mampu untuk mempertahankan keberadaan dan melakukan alternatif pengembangan usaha pengolahan (Chaidir et al., 2018).

\section{PROFIL PERIKANAN BUDI DAYA PATIN KABUPATEN MUARO JAMBI}

Kabupaten Muaro Jambi termasuk sentra produksi perikanan yang cukup potensial, hal ini tidak terlepas dari kondisi geografis wilayah yang dialiri Sungai Batang Hari yang sangat baik untuk budi daya ikan perairan umum serta geografis wilayah yang mempunyai cukup banyak lahan basah atau rawa. Pengembangan budi daya perikanan utama dibagi atas dua kelompok, yaitu 1) Perairan umum, dilakukan sepanjang Sungai Batang Hari, dengan sistem keramba jaring apung (KJA) yang terpusat di Kecamatan Jambi Luar Kota, Sekernan, Muaro Sebo, dan Kumpe Hilir; serta 2) Budi daya kolam, dilakukan di dataran rendah/berawa yang banyak terdapat di Kecamatan Sungai Gelam dan Kumpeh Ulu.

Luas wilayah Kabupaten Muaro Jambi adalah $5.246 \mathrm{~km}^{2}$ yang terdiri atas 11 kecamatan, 145 desa, dan 5 kelurahan. Dari 11 kecamatan yang ada di Kabupaten Muaro Jambi, kecamatan penghasil patin terbesar adalah Kecamatan Kumpeh Ulu dan Kecamatan Sungai Gelam. Produksi ikan patin di Kecamatan Kumpeh Ulu 
mengalami penurunan dari $10.200,5$ ton pada tahun 2015 menjadi $9.732,0$ ton pada tahun 2016 dan mengalami kenaikan pada tahun 2017 menjadi $9.825,7$ ton, sedangkan di Kecamatan Sungai Gelam, jumlah produksi terus naik dari tahun 2015, yaitu $3.775,5$ ton; $3.869,3$ ton pada tahun 2016 ; dan 3.922,4 ton pada tahun 2017 (Dinas Kelautan dan Perikanan [DKP] Kabupaten Muaro Jambi, 2018). Fluktuatifnya produksi tersebut disebabkan oleh sistem budi daya yang menggunakan kolam tanah dengan sumber air dari tadah hujan sehingga kualitas media budi daya tergantung dari cuaca yang akan berdampak pada kematian ataupun serangan penyakit pada ikan.

Pengembangan budi daya perikanan di 2 (dua) kecamatan tersebut adalah budi daya dengan media kolam tanah. Kemampuan tersebut didukung oleh kondisi geografis wilayah yang berada di dataran rendah dan mempunyai cukup banyak lahan basah/rawa. Komoditas yang cocok untuk dibudidayakan di lahan tersebut adalah ikan patin dikarenakan dapat tumbuh dengan baik dan dapat dikembangkan di lahan marginal, seperti lahan rawa maupun lahan gambut (Widodo et al., 2010). Kawasan budi daya ikan patin di Kecamatan Kumpeh Ulu dikembangkan oleh 21 kelompok budi daya, sedangkan di Kecamatan Sungai Gelam terdiri dari 6 kelompok dengan jumlah kolam > 2000 petak kolam.

Pemanfaatan lahan oleh masyarakat di Kecamatan Kumpeh Ulu dan Kecamatan Sungai Gelam digunakan untuk berbagai keperluan, seperti pertanian, perikanan, perkebunan, dan lain sebagainya. Pemanfaatan lahan untuk kegiatan budi daya patin paling banyak terdapat di Desa Pudak, Desa Kota Karang, Desa Lopak Alai, dan sebagian di Desa Tarikan, Desa Sakean, dan Desa Tangkit Baru. Status kepemilikan lahan kolam budi daya sebagian besar adalah $74 \%$ milik sendiri, selebihnya, status kepemilikan lahan budi daya adalah lahan sewa dan milik orang lain yang digunakan dengan sistem bagi hasil. Menurut Anwar (2013), status kepemilikan lahan dapat meningkatkan produksi dan menjadi faktor yang mendukung dalam meraih kepercayaan untuk kerja sama dengan pihak yang terkait.

Kegiatan budi daya ikan patin dilakukan pada kolam tanah dengan luas kolam untuk budi daya bervariasi mulai ukuran terkecil, yaitu $10 \times 20 \mathrm{~m}^{2}$ hingga ukuran terbesar, yaitu $50 \times 180 \mathrm{~m}^{2}$. Kolam dibentuk dari penggalian tanah cekungan baik lahan basah/rawa maupun lahan kosong yang belum termanfaatkan namun posisinya cukup rendah. Sumber air untuk kegiatan budi daya patin berasal dari resapan air tanah dan tadah hujan. Selain itu, terdapat satu pembudi daya yang menggunakan tandon. Kondisi air kolam budi daya yang ada di Kabupaten Muaro Jambi tidak menggunakan kincir air serta tidak memiliki saluran pemasukan maupun pembuangan air sehingga tidak ada resirkulasi air di dalam kolam tersebut. Hal yang dilakukan oleh pembudi daya adalah melakukan penyedotan air dan lumpur setiap selesai pemanenan. Efendi et al. (2012) mengatakan bahwa keberadaan kolam tandon tersebut sangat penting dalam kegiatan budi daya dikarenakan kegiatan budi daya perikanan umumnya membutuhkan lebih banyak air per unit area, yang artinya ketersediaan sumber air yang berkualitas sering kali menentukan keberhasilan atau kegagalan usaha budi daya perikanan.

Sumber benih berasal dari Balai Budidaya Air Tawar (BBAT) Sungai Gelam serta Unit Pembenihan Rakyat (UPR) sekitar, seperti UPR Jambi Seberang, UPR Kota Karang, dan UPR milik kelompok sendiri dengan induk berasal dari BBAT Sungai Gelam. UPR Jambi Seberang adalah UPR yang terletak di wilayah Kota Jambi, yang merupakan penghasil terbesar benih yang ada di Provinsi Jambi, yaitu $45,7 \%$ dan diikuti oleh UPR yang ada di Muaro Jambi sebesar 19\% (DKP Provinsi Jambi, 2018). Ketersediaan benih merupakan hal penting yang harus diperhatikan karena benih menjadi faktor penghambat produktivitas perikanan bukan hanya dari segi kuantitas tetapi juga dari segi kualitas (Wijaya \& Rachmawati, 2017). Menurut Pramono et al. (2019), keberhasilan dalam usaha pembesaran ikan patin sangat ditentukan oleh input produksi (dalam hal ini adalah benih ikan patin) yang bermutu serta proses produksi yang baik sehingga akan mempengaruhi output pembesaran ikan patin yang dihasilkan.

Seleksi benih yang dilakukan adalah dengan membeli benih yang berukuran 1,5-2 inci yang dibeli dengan harga Rp170,00-Rp200,00. Alasan menggunakan benih dengan ukuran tersebutadalah apabila ukuran benih terlalu kecil menyebabkan banyak benih yang mati. Rata-rata benih yang ditebar setiap kolamnya bervariasi sesuai dengan ukuran kolam dan hasil akhir yang diinginkan mulai dari 4.000 ekor benih untuk kolam ukuran $10 \times 20$ $\mathrm{m}^{2}$ dan 120.000 ekor benih untuk kolam ukuran $50 \times 180 \mathrm{~m}^{2}$. Jumlah produksi ikan patin yang dihasilkan dari kegiatan budi daya berkisar mulai dari 2 ton hingga 40 ton untuk ukuran kolam paling 
besar dengan lama waktu pemeliharaan ikan patin adalah 6 (enam) sampai 7 (tujuh) bulan.

Hasil survei dan wawancara terhadap 57 orang responden pembudi daya patin menunjukkan bahwa sebanyak $91 \%$ (52 orang) pembudi daya menggunakan pakan pabrikan dari berbagai merek dagang, sedangkan 9\% (6 orang) lainnya menggunakan pakan mandiri yang dibuat dengan menggunakan campuran ikan rucah, dedak, dan poles. Tingginya penggunaan pakan pabrikan dikarenakan sulitnya memperoleh bahan baku pakan mandiri. Menyikapi permasalahan ini, Dinas Kelautan dan Perikanan Provinsi Jambi saat ini berupaya menjalin kerja sama dengan salah satu universitas guna menekan biaya produksi pakan yang murah dengan nutrisi dan protein yang baik untuk pertumbuhan ikan yang sesuai dengan cara pembuatan pakan ikan yang baik (CPPIB), serta mensosialisasikan kembali gerakan pakan ikan mandiri (Gerpari) dengan memberikan bantuan berupa mesin pencetak pakan kepada pembudi daya.

Kegiatan budi daya mendapat perhatian dari pemerintah pusat maupun daerah, pembudi daya didorong dan dilakukan pembinaan agar melakukan kegiatan dengan memperhatikan proses produksi supaya memperoleh hasil yang baik, salah satunya dengan menerapkan cara budi daya ikan yang baik (CBIB). CBIB merupakan panduan dalam memproduksi ikan dengan memperhatikan kualitas produk yang memiliki daya saing, ramah lingkungan, berkelanjutan, aman dikonsumsi, dan mampu telusur. Pembudi daya ikan patin yang ada di Kabupaten Muaro Jambi umumnya belum memperoleh sertifikat CBIB (saat ini dalam proses penyiapan menuju sertifikasi $\mathrm{CBIB}$ ). Sebagian pembudi daya sudah menerapkan CBIB berdasarkan hasil kegiatan pelatihan, penyuluhan, dan komunikasi antar pembudi daya.

Modal merupakan faktor penunjang utama dalam kegiatan budi daya yang dapat meningkatkan produksi. Pembudi daya akan kesulitan untuk mengembangkan usahanya karena keterbatasan modal akan mempengaruhi produktivitas hasil usaha secara optimal (Aprolita, 2008). Sumber perolehan modal dalam menjalankan kegiatan budi daya menunjukkan bahwa $51 \%$ pembudi daya memiliki modal pribadi, sedangkan $49 \%$ lainnya berasal dari peminjaman modal. Keterbatasan modal mendorong pembudi daya melakukan kemitraan dengan pihak lain, seperti tauke pakan dan perbankan. Keuntungan dari kemitraan dengan tauke pakan adalah ketersediaan pakan yang merupakan faktor produksi terbesar bisa ditanggulangi, tetapi, terdapat kesepakatan bahwa hasil produksi diambil oleh pemberi modal sehingga faktor harga dan waktu panen menjadi permasalahan karena diatur oleh pemilik modal. Permodalan yang berasal dari perbankan hanya dilakukan oleh $5 \%$ pembudi daya, dikarenakan lembaga perbankan meminta agunan sebagai jaminan.

Kegiatan budi daya ikan patin di Muaro Jambi, seperti pemberian pakan dan pembersihan kolam menunjukkan bahwa pembudi daya hanya melibatkan anggota keluarga dalam kegiatan budi daya dengan jumlah berkisar $1-3$ orang, sedangkan kegiatan pemanenan melibatkan tenaga kerja di luar anggota keluarga (upahan) dengan jumlah berkisar 4-10 orang. Hasil penelitian yang dilakukan oleh Aprolita (2008) menunjukkan jumlah penggunaan tenaga kerja oleh pembudi daya paling rendah 1 orang dan paling tinggi antara 4-12 orang.

\section{ASPEK KELEMBAGAAN}

Menurut Yulisti dan Triyanti (2012), kelembagaan merupakan sekumpulan jaringan orang-orang dari relasi sosial yang memiliki tujuan tertentu, yang diatur oleh aturan dan norma serta memiliki struktur. Berdasarkan Keputusan Menteri Kelautan dan Perikanan Nomor 14 Tahun 2012 Tentang Pedoman Umum Penumbuhan dan Pengembangan Kelembagaan Pelaku Utama Perikanan, istilah kelembagaan terdiri atas kelembagaan penyuluhan pemerintah, kelembagaan penyuluhan swasta dan kelembagaan penyuluhan swadaya. Kelembagaan pelaku utama kegiatan perikanan dapat berbentuk kelompok, gabungan kelompok, asosiasi ataupun korporasi.

Kelembagaan kelompok budi daya sudah berjalan cukup efektif, yaitu melalui pembentukan kelompok. Kelembagaan pelaku utama kegiatan perikanan yang dibentuk untuk pembudi daya ikan berbentuk Pokdakan (Kelompok Pembudi Daya Ikan), sedangkan kelembagaan pelaku utama kegiatan di pengolahan ikan disebut Poklahsar (Kelompok Pengolah dan Pemasar Ikan). Pokdakan beranggotakan $10-15$ orang yang diketuai oleh seorang ketua kelompok. Pokdakan menjadi suatu wadah bagi para pembudi daya serta sebagai forum diskusi, advokasi, dan sharing informasi terkait kegiatan budi daya. Peran kelembagaan kelompok pembudi daya ikan sangat penting dalam 
membantu kegiatan lembaga penyuluhan untuk menyampaikan informasi terkait kegiatan budi daya, sebagai media informasi dan komunikasi bagi anggota kelompok (Wiramiharja, 2017). Menurut Utami (2019), penguatan kelembagaan dilakukan melalui beberapa upaya, antara lain, mendorong dan membimbing petani agar mampu bekerja sama di bidang ekonomi secara kelompok, menumbuh kembangkan kelompok melaluipeningkatan fasilitas bantuan dan akses permodalan, peningkatan posisi tawar, peningkatan fasilitas dan pembinaan kepada organisasi, peningkatan efisiensi dan efektivitas usaha, serta peningkatan kapasitas SDM melalui berbagai kegiatan pendampingan dan pelatihan yang dirancang khusus bagi pengurus dan anggota.

Pokdakan didampingi oleh tenaga penyuluh perikanan dari Dinas Perikanan Kabupaten Muaro Jambi. Lembaga penyuluhan berperan mendampingi, memberikan pembinaan, serta transfer teknologi dan informasi bagi pembudi daya. Kecamatan Kumpeh Ulu terdiri dari 21 Pokdakan yang didampingi penyuluh perikanan bantu sebanyak 3 orang, sedangkan di Kecamatan Sungai Gelam terdapat enam Pokdakan yang didampingi 1 orang. Berbeda halnya dengan Poklahsar, setiap Poklahsar dilakukan pendampingan dan bimbingan teknis oleh subbagian pengolahan dan pemasaran produk dari Dinas Perikanan Kabupaten Muaro Jambi.

Di Provinsi Jambi terdapat satu asosiasi budi daya, yaitu asosiasi pembudi daya patin yang diberi nama AP2J (Asosiasi Pembudi Daya Patin Jambi) yang terdiri dari berbagai kelompok pembudi daya (Pokdakan). Kondisi saat ini AP2J sudah tidak aktif dikarenakan banyaknya pembudi daya yang tidak produksi dan tidak beroperasinya unit pengolahan fillet ikan di Desa Kemingking Kabupaten Muaro Jambi. Keberadaan suatu asosiasi dapat menjadi wadah komunikasi antar pembudi daya terkait segala hal dan informasi mulai dari kegiatan budi daya hingga pemasaran (Putinur et al., 2019). Menurut Marasabessy dan Najamuddin (2015), interaksi antar aktor dalam suatu kelembagaan perlu diperhatikan karena suatu lembaga merupakan media untuk bermusyawarah terkait persoalan yang dihadapi dan kemudian mencari solusi pemecahannya dengan tetap melakukan koordinasi serta memberikan informasi kepada pemerintah dengan harapan ada campur tangan pemerintah untuk mengatasinya. Dukungan pemerintah menjadi salah satu faktor yang menentukan keberhasilan budi daya melalui keterlibatan lembaga pemerintah dalam melengkapi sistem dukungan pelayanan bagi pengembangan usaha perikanan (Sushanty, et al. 2017).

Kelembagaan permodalan yang terdapat di lokasi penelitian adalah lembaga perbankan dan koperasi. Permodalan yang berasal dari lembaga perbankan tidak semua dapat diakses oleh pembudi daya, dikarenakan pihak perbankan menerapkan sistem agunan, sedangkan pembudi daya tidak memiliki sesuatu untuk dijadikan agunan. Kelembagaan koperasi di Kabupaten Muaro Jambi hanya terdapat satu unit koperasi, tetapi tidak operasional untuk dapat diakses oleh para pembudi daya patin di Kabupaten Muaro Jambi (akses peminjaman modal hanya diperuntukkan bagi anggota Pokdakan). Koperasi tersebut merupakan milik salah satu Pokdakan yang dijadikan sebagai wadah bagi anggota Pokdakan untuk memasarkan hasil panen, menyediakan pakan pabrikan, serta menyediakan peralatan dan keperluan lainnya yang digunakan untuk kegiatan budi daya. Selain itu, koperasi tersebut juga menyediakan jasa bagi pembudi daya patin lainnya berupa tenaga kerja upahan harian untuk kegiatan pemanenan serta penyewaan peralatan untuk kegiatan pemanenan ikan patin.

\section{ASPEK TEKNOLOGI}

Penggunaan dan penerapan teknologi merupakan salah satu faktor yang dapat membantu perolehan hasil yang optimal. Tingkat penerapan serta penguasaan teknologi di kalangan pembudi daya menunjukkan tingkat kemandirian pembudi daya. Teknologi yang digunakan oleh pembudi daya patin yang ada di Provinsi Jambi saat ini masih tergolong sederhana dan belum menerapkan teknologi modern. Kondisi di beberapa desa terlihat bahwa ada beberapa kolam budi daya terserang penyakit ikan yang disebabkan oleh bakteri Edwarsiella ichtaluri. Keterbatasan informasi mengenai pengobatan penyakit tersebut serta belum ada lagi produksi vaksin ikan patin mengakibatkan para pembudi daya melakukan cara tradisional yang telah dilakukan turun temurun dan dipercaya mampu mengatasi penyakit tersebut, salah satunya penggunaan daun pepaya yang dihancurkan dan selanjutnya diberikan ke ikan patin yang ada di kolam budi daya.

Kondisi air kolam budi daya tidak menggunakan kincir air serta tidak memiliki saluran pemasukan maupun pembuangan air sehingga tidak ada resirkulasi air di dalam kolam tersebut. Hal yang 
dilakukan oleh pembudi daya adalah penyedotan air dan lumpur setiap selesai pemanenan. Tingkat penguasaan teknologi budi daya ikan patin lebih menekankan kepada pengusaan cara budi daya ikan yang baik (CBIB). Pembudi daya ikan patin umumnya belum memperoleh sertifikat CBIB dan beberapa lainnya sedang dalam proses penyiapan menuju sertifikasi CBIB. Walaupun demikian, pembudi daya sudah menerapkan teknologi budi daya berdasarkan hasil dari kegiatan pelatihan, penyuluhan, dan komunikasi antar pembudi daya. CBIB merupakan panduan dalam memproduksi ikan dengan memperhatikan kualitas produk yang memiliki daya saing, ramah lingkungan, berkelanjutan, aman dikonsumsi, dan mampu telusur.

\section{ASPEK PEMASARAN}

Aktivitas bisnis yang dilakukan oleh pembudi daya dan pengolah tidak akan terlepas dari kegiatan pemasaran. Kegiatan ini merupakan kunci utama dalam penyampaian produk kepada para konsumen pada pasar yang dituju. Menurut Triyanti dan Shafitri (2012), pemasaran produk merupakan salah satu komponen pascaproduksi yang perlu mendapat perhatian lebih karena merupakan kunci dalam pengembangan usaha. Produk perikanan yang bersifat mudah rusak (perishable food), mengharuskan pemasaran yang membutuhkan perhatian khusus. Ikan patin yang diproduksi dapat memenuhi kebutuhan pasar lokal yang ada di Provinsi Jambi, seperti Pasar Angso Duo yang terletak di Kota Jambi, serta pasarpasar yang ada di kabupaten lainnya yang ada di Provinsi Jambi. Namun, serapan pasar jika dibandingkan dengan jumlah produksi harian ikan patin di Provinsi Jambi masih mampu menyerap seluruh hasil produksi patin di Provinsi Jambi. Permintaan pasar terhadap patin per hari berkisar antara 23 hingga 25 ton. Selain itu, ikan patin juga dikirim ke luar daerah, seperti Lubuk Linggau, Lahat, Tembilahan, Batam, dan Medan. Kepala Dinas Kelautan dan Perikanan Provinsi Jambi (disitasi dalam Juanda, 2018) menyatakan bahwa permintaan pasar Angso Duo di Kota Jambi adalah 8 ton ikan patin per hari, sedangkan keluar Provinsi Jambi sebanyak 20 ton dengan tujuan pemasaran ke Sumatra Barat, Bengkulu, Sumatra Selatan, dan Riau.

Ikan patin dipasarkan dalam bentuk hidup/ segar maupun dalam berbagai bentuk produk olahan. Permintaan pasar terhadap ikan patin beragam ukuran mulai dari ukuran 500 gram sampai 1 kilogram per ekor. Ukuran ikan yang diminati konsumen yang dijual ke pasar bobotnya berkisar antara 500-700 gram/ekor, sedangkan untuk unit pengolahan bobot ikan yang diinginkan lebih dari 700 gram/ekor.

Pemasaran yang dilakukan oleh pembudi daya patin di Muaro Jambi terbagi menjadi tiga, yaitu pemasaran yang dilakukan secara mandiri, kerja sama dengan tauke pakan, dan kerja sama dengan koperasi. Pemasaran secara mandiri adalah pemasaran yang dilakukan oleh pembudi daya dengan mencari langsung target pasar tanpa menggunakan perantara. Pemasaran dengan mitra tauke pakan adalah pemasaran yang dilakukan oleh para pembudi daya ke tauke pakan yang bertindak sebagai penyedia pakan sekaligus sebagai penampung hasil panen pembudi daya. Selanjutnya, pemasaran yang dilakukan dengan koperasi adalah pemasaran yang dilakukan oleh pembudi daya yang menjalin kerja sama dengan koperasi dengan Memorandum of Understanding (MoU) yang telah disepakati. Berdasarkan hasil wawancara kegiatan pemasaran, sebagian besar hasil budi daya patin (sebanyak $56 \%$ ) dipasarkan melalui kerja sama pemasaran hasil panen kepada penyuplai pakan (tauke pakan), pemasaran secara mandiri (33\%), dan sisanya (11\%) pemasaran di koperasi.

Unit pengolahan ikan patin di Kabupaten Muaro Jambi melakukan pemasaran secara mandiri. Daerah pemasaran produk dari UMKM Tunas Baru adalah Jakarta (Carrefour), Bandar Udara Sultan Thaha Saifuddin Provinsi Jambi, dan swalayan-swalayan yang ada di Kota Jambi. Selain itu, abon yang diproduksi oleh UMKM Tunas Baru juga diminati oleh Kementerian Agama Provinsi Jambi sehingga sering dijadikan bekal calon jamaah haji Provinsi Jambi. Pemasaran produk stick ikan milik UMKM Indri Jaya hanya dilakukan di swalayan-swalayan yang ada di Kota Jambi. Pemasaran produk olahan dilakukan dengan menjual langsung produk dan mengantarkan produk ke target pasar yang telah ada.

\section{PERMASALAHAN DAN KENDALA YANG DIHADAPI}

Permasalahan-permasalahan yang dihadapi oleh pembudi daya patin secara umum adalah pemasaran. Produksi perikanan patin di Muaro Jambi terus mengalami peningkatan, tetapi tidak diiringi dengan perkembangan industri hilirisasi 
perikanan dan pemasaran (Zulkifli, 2019). Pemasaran ikan patin di Provinsi Jambi masih terbatas pada konsumsi segar dan pengolahan tradisional, sedangkan untuk pengolahan modern seperti fillet patin saat ini sudah tidak dijalankan. Hal ini dikarenakan UPI yang memproduksi fillet patin di Provinsi Jambi sudah tidak beroperasional lagi. Tidak beroperasionalnya UPI tersebut dikarenakan sulitnya memperoleh bahan baku ikan patin yang memenuhi kriteria untuk dijadikan fillet, harga bahan baku yang tidak sesuai dengan keinginan perusahaan maupun pembudi daya serta jarak pasar yang mengakibatkan rendahnya margin yang diperoleh.

Akses pemasaran ikan patin sebagian besar dilakukan di dalam Provinsi Jambi dan beberapa daerah di provinsi lainnya. Sulitnya akses pemasaran di luar daerah dikarenakan letak Provinsi Jambi yang berada di tengah-tengah provinsi yang juga menjadi sentra perikanan patin di Indonesia, seperti Sumatra Selatan, Riau, dan Lampung. Sulitnya akses pemasaran ikan patin di Muaro Jambi mengakibatkan banyak pembudi daya yang sudah tidak beroperasi lagi, seperti yang terjadi di Kecamatan Sungai Gelam, yaitu di Desa Tangkit Baru, terlihat bahwa banyak kolam kosong yang sudah tidak digunakan lagi.

Harga pakan komersial (pabrikan) yang cukup mahal dan rendahnya harga jual ikan patin menjadi permasalahan tersendiri di kalangan pembudi daya. Pembudi daya tidak memiliki alternatif pakan lain selain pakan pabrikan, hal ini dikarenakan sulitnya memperoleh bahan baku untuk pembuatan pakan mandiri, yaitu ikan rucah, dedak, dan poles. Mahalnya harga pakan komersil yang dibarengi dengan ketidakseimbangan dengan harga jual ikan patin membuat pembudi daya mengeluh dan berpikir dua kali untuk melanjutkan usaha budi daya, mengingat masa pemeliharaan ikan patin yang cukup lama, yaitu 6 sampai 7 bulan dan tidak adanya alternatif pakan pengganti. Pakan harus mendapat perhatian yang serius karena pakan akan mempengaruhi pertumbuhan berat ikan, nutrisi ikan, dan merupakan bagian terbesar dari biaya operasional dalam pemeliharaan ikan patin (Komariyah \& Setiawan, 2009). Kordi (2005) menyatakan bahwa sekitar 50-60\% biaya produksi dikeluarkan untuk biaya pakan. Oleh karena itu, manajemen pakan berupa pemilihan pakan atau pembuatan pakan, pengadaan, dan pemberian pakan yang terbaik harus diterapkan untuk menekan biaya produksi yang semakin tinggi.
Kurangnya ketersediaan benih dan sulitnya memperoleh benih yang berkualitas menjadi sorotan, dikarenakan banyaknya ikan patin yang terserang penyakit. Penyakit yang dialami ikan patin mulai dari tidak mau makan hingga kematian massal. Kematian ini mayoritas terjadi saat ukuran ikan masih kecil, yaitu 2-3 jari. Penyebaran virus atau penyakit ikan yang begitu cepat sangat sulit diprediksi dan belum ada cara yang efektif dan efisien untuk pencegahannya sehingga menghambat produktivitas dan menimbulkan kerugian bagi para pembudi daya.

Kondisi di beberapa desa di Kecamatan Kumpeh Ulu terlihat bahwa beberapa kolam budi daya terserang penyakit ikan yang disebabkan oleh bakteri Edwarsiella ichtaluri. Keterbatasan informasi mengenai pengobatan penyakit tersebut serta belum ada lagi produksi vaksin ikan patin mengakibatkan para pembudi daya melakukan cara tradisional yang telah dilakukan turun temurun dan dipercaya mampu mengatasi penyakit tersebut, salah satunya penggunaan daun dan buah pepaya yang dihancurkan dan diberikan ke ikan patin yang ada di kolam budi daya. Pembudi daya juga memberikan probiotik serta mempuasakan ikan. Selain itu, kegiatan pemanenan dilakukan dengan segera meskipun umur dan ukuran ikan belum mencukupi permintaan pasar, akibatnya, pembudi daya ikan patin merugi. Hikmayani et al. (2012) menyebutkan bahwa faktor dominan yang mempengaruhi usaha budi daya ikan patin di Kabupaten Muaro Jambi secara teknis adalah penyakit ikan, kualitas benih, dan kualitas pakan.

Keterbatasan modal yang dimiliki oleh pembudi daya untuk memenuhi ketersediaan pakan mengakibatkan pembudi daya melakukan peminjaman modal ke tauke pakan, dengan konsekuensi hasil panen dijual kepada peminjam modal. Akibatnya, harga jual serta waktu panen ditentukan oleh tauke pakan. Di sisi lain, pemasaran yang dilakukan kepada tauke pakan juga kerap terjadi antrian, akibatnya, pembudi daya harus menunggu antrian untuk pemanenan yang bisa mencapai 1 bulan lamanya. Hal ini mengakibatkan bertambahnya biaya produksi.

Permasalahan lain yang dihadapi oleh beberapa pembudi daya di beberapa desa di Kecamatan Kumpeh Ulu adalah akses jalan yang saat ini rusak dan tidak adanya penerangan. Kondisi jalan berupa tanah yang tidak rata dan digenangi air mengakibatkan sulit untuk dilalui 
jika musim hujan tiba. Hal ini mengakibatkan terhambatnya proses produksi, khususnya saat kegiatan pemanenan dilakukan, terlebih jika proses pemanenan dilakukan pada malam hari.

Harapan dari pembudi daya terhadap pemerintah terkait budi daya patin, antara lain:

1. Terbukanya akses jaringan pemasaran yang luas serta adanya penampung tetap hasil panen sehingga daya serap terhadap ikan patin terus meningkat yang ditandai dengan meningkatnya volume penjualan, meningkatnya jumlah daerah regional tujuan pemasaran, meningkatnya jumlah investor penampung hasil panen, dan meningkatnya angka konsumsi ikan. Salah satu upaya membuka akses pemasaran adalah dengan merevitalisasi kembali UPI fillet ;

2. Tersedianya bantuan modal untuk pembelian benih dan pakan;

3. Pemerintah turun tangan dalam mengontrol harga pakan dan harga jual ikan yang tidak stabil, yang saat ini dikuasai oleh para tengkulak;

4. Perbaikan akses jalan dan penerangan di Kecamatan Kumpeh Ulu;

5. Penyediaan bahan baku untuk pembuatan pakan mandiri agar pembudi daya tidak lagi bergantung pada pakan pabrikan yang harganya semakin naik;

6. Pelatihan di bidang perikanan, seperti CPIB dan CBIB serta pelatihan lainnya yang dapat menunjang kegiatan budi daya.

Permasalahan yang dihadapi oleh unit pengolahan adalah pemasaran. Terbatasnya akses informasi pasar menjadi permasalahan tersendiri di kalangan pengolah. Hal ini terlihat dari berkurangnya jumlah pengolah ikan yang ada di Kabupaten Muaro Jambi. Berdasarkan data unit pengolahan patin di Muaro Jambi, terdapat 25 kelompok pengolah, tetapi setelah dilakukan survei ke lapangan ternyata hanya tersisa 2 unit pengolahan saja yang masih aktif melakukan proses produksi. Berkurangnya jumlah unit pengolahan ikan di Kabupaten Muaro Jambi juga disebabkan oleh berkurangnya jumlah pembudi daya di Kecamatan Sungai Gelam. Sebagian besar unit pengolahan skala UMKM sudah tidak beroperasional dalam memproduksi abon. Di sisi lain, minat konsumen untuk mengkonsumsi abon terbatas pada kalangan menengah ke atas karena mahalnya harga abon untuk kalangan bawah. Selain itu, daya tahan produk abon juga tidak bertahan lama sehingga sering kali dikembalikan oleh swalayan tempat memasarkan produk (tidak laku).

Permasalahan lainnya yang dihadapi oleh UMKM Tunas Baru dan UMKM Indri Jaya adalah keterbatasan tenaga pemasaran dan jauhnya jarak unit pengolahan dengan target pasar. Pengolah kekurangan tenaga untuk memantau kondisi produk di pasar, memastikan produk yang terjual, yang rusak ataupun kadaluarsa di swalayan, akibatnya, pengolah tidak memiliki target produksi untuk produk olahan. Harapan dari pengolah terhadap permasalahan yang ada, antara lain,

1. Terbukanya akses dan informasi pasar sehingga daya serap pasar terhadap produk olahan patin meningkat yang ditandai dengan meningkatnya volume penjualan produk olahan ikan patin, meningkatnya jumlah daerah regional untuk pemasaran, meningkatnya diversifikasi produk dari ikan patin, bertambahnya jumlah UMKM yang terbina, serta meningkatnya angka konsumsi ikan;

2. Perbaikan ruang produksi yang sesuai dengan standar Sertifikasi Kelayakan Pengolahan (SKP);

3. Adanya pelatihan-pelatihan terkait inovasi dan diversifikasi produk dari ikan patin maupun pengembangan usaha serta pelatihan lainnya.

\section{PENUTUP}

Penunjukan Provinsi Jambi sebagai salah satu sentra patin nasional belum berhasil, hal ini terlihat dari kondisi industri budi daya terkini di Provinsi Jambi yang menunjukkan bahwa pembudi daya mengalami beberapa permasalahan, antara lain, keterbatasan modal usaha, serangan penyakit, sulitnya memperoleh bahan baku pembuatan pakan mandiri, harga pakan yang tinggi, serta masalah utamanya adalah terbatasnya akses pemasaran. Di sektor industri pengolahan, kondisi yang ada saat ini terlihat adalah banyaknya jumlah unit pengolahan yang tidak beroperasi baik unit pengolahan skala UMKM maupun skala besar, seperti UPI fillet patin. Permasalahan umum yang dihadapi pengolah adalah terbatasnya akses pemasaran.

Berdasarkan permasalahan di atas maka rekomendasi yang dapat diusulkan, antara lain, adanya program sentra patin nasional sebagai 
salah satu agenda di RPJMD atau Renstra DKP Provinsi Jambi, pemerintah merevitalisasi kembali unit pengolahan fillet ikan patin, terbukanya akses pemasaran, dan ketersediaan penampung tetap hasil panen pembudi daya, serta adanya informasi penyedia bahan baku untuk pembuatan pakan mandiri.

\section{UCAPAN TERIMA KASIH}

Penulis mengucapkan terima kasih kepada Dinas Kelautan dan Perikanan Provinsi Jambi, Dinas Perikanan Kabupaten Muaro Jambi, Penyuluh Perikanan Bantu (PPB) Kabupaten Muaro Jambi (pak Luqman, bu Asri Arti Erfita, dan pak Febri) yang telah mendampingi penulis selama penelitian, serta terima kasih kepada para responden yang terlibat dalam penelitian ini atas informasi dan penilaian yang telah diberikan.

\section{PERNYATAAN KONTRIBUSI PENULIS}

Dengan ini kami menyatakan bahwa kontribusi masing-masing penulis terhadap pembuatan karya tulis adalah Putinur, Randi B. S. Salampessy, dan Achmad Poernomo sebagai kontributor utama. Penulis menyatakan bahwa telah melampirkan surat pernyataan kontribusi penulis.

\section{DAFTAR PUSTAKA}

Anwar, A. (2013). Analisis kebijakan dan strategi pengembangan usaha rumput laut euchema cottoni di Kabupaten Bantaeng (Studi kasus di Kecamatan Bissappu, Bantaeng dan Paa'jukukang). Octopus Jurnal Ilmu Perikanan, 1(2), 103-109. https://doi.org/10.26618/octopus. v2i1.521

Aprolita. (2008). Kemandirian pembudidaya ikan patin di kolam lahan gambut di Desa Tangkit Baru, Kec Kumpeh Ulu, Kab Muaro Jambi, Provinsi Jambi. [Tesis, Institut Pertanian Bogor].

Asmaida \& Rogayah. (2020). Peran dan kontribusi curahan waktu kerja wanita pada usaha pembesaran ikan patin (pangasius $\mathrm{sp}$ ) dalam kolam (Studi kasus di Desa Pudak Kecamatan Kumpeh Ulu Kabupaten Muaro Jambi). Jurnal MeA (Media Agribisnis), 5(2), 74-82. http://dx.doi.org/10.33087/mea.v5i2.78

Asmaida, Mulyani, Kemala, N., \& Syahrizal. (2019). Relationship between perception and consumers' preferences of patin fish. International Journal of Scientific \& Technology Research (IJSTR), 8(10), 2689-2693. http://www.ijstr.org/
final-print/oct2019/Relationship-Between-Perception-And-Consumers-Preferences-Of-Patin-Fish-.pdf

Burhan, U. M. (2004). Wawasan studi kelayakan dan evaluasi proyek. Bumi Aksara.

Chaidir, N., Napitupulu, D., \& Sardi, I. (2018). Strategi pengembangan agroindustri ikan patin (Studi kasus di Desa Pudak Kecamatan Kumpeh Ulu Kabupaten Muaro Jambi). Jurnal IImiah Sosio-Ekonomika Bisnis, 21(1), 1-13. https://doi.org/10.22437/jiseb.v21i1.5099

Cocon. (2018). Akuakultur dalam perspektif pembangunan berkelanjutan. Kencana Batu Pualam (KRP) Press.

Direktorat Jenderal Perikanan Budidaya [DJPB]. (2019). Statistik perikanan budidaya 2018. Kementerian Kelautan dan Perikanan.

Dinas Kelautan dan Perikanan [DKP] Kabupaten Muaro Jambi. (2018). Buku statistik perikanan tahun 2018. Pemerintah Daerah Kabupaten Muaro Jambi, Provinsi Jambi.

Dinas Kelautan dan Perikanan [DKP] Provinsi Jambi. (2020). Buku tahunan kelautan dan perikanan dalam angka Dinas Kelautan dan Perikanan Provinsi Jambi tahun 2020. Dinas Kelautan dan Perikanan Provinsi Jambi.

Efendi, Zairin, \& Mulyadi. (2012). Budidaya perikanan. Buku Materi Pokok MMP15201. Universitas Terbuka.

Hikmayani, Y., Yulisti, M., Hikmah. (2012). Evaluasi kebijakan peningkatan produksi perikanan budidaya. Jurnal Kebijakan Sosial Ekonomi Kelautan dan Perikanan, 2(2), 85-102. http:// dx.doi.org/10.15578/jksekp.v2i2.9277

Juanda. (2018, 19 Desember). Jambi pasok ikan patin 20 ton per hari keluar daerah. Kajanglako. http://m. kajanglako.com/id-6711-post-jambi-pasok-ikanpatin-20-ton-perhari-ke-luar-daerah-.html

Keputusan Menteri Kelautan dan Perikanan Nomor 14 Tahun 2012. (2012). Pedoman umum penumbuhan dan pengembangan kelembagaan pelaku utama perikanan. Kementerian Kelautan dan Perikanan

Komariyah, \& Setiawan, A. I. (2009). Pengaruh penambahan berbagai dosis minyak ikan yang berbeda pada pakan buatan terhadap pertumbuhan benih ikan patin (Pangasius pangasius). PENA Akuatika, 1(1), 19-29. http:// dx.doi.org/10.31941/penaakuatika.v1i1.253

Kordi, K. M. G. H. (2005). Budidaya ikan patin biologi, pembenihan dan pembesaran. Yayasan Pustaka Nusatama. 
Marasabessy, A. Z., \& Najamuddin. (2015). Analisis kelembagaan pengelolaan sumberdaya perikanan di Kabupaten Maluku Tengah. Octopus Jurnal IImu Perikanan, 4(1), 320-326. https:// doi.org/10.26618/octopus.v4i1.567

Pramono, T., Suryahadi., \& Trilaksani, W. (2019). Strategi pengembangan usaha dan pemasaran benih ikan patin siam (Pangasianodon hypopthalmus) dengan sistem jejaring pada cabang Dinas Kelautan dan Perikanan Wilayah Utara Provinsi Jawa Barat. Manajemen IKM, 14(1), 15-23._https://doi.org/10.29244/ mikm.14.1.15-23

Putinur, Salampessy, R. B. S., Poernomo, A. (2019). Strategi pengembangan industri patin di Provinsi Jambi. Buletin IImiah Marina Sosial Ekonomi Kelautan dan Perikanan, 5(2), 53-68. http:// dx.doi.org/10.15578/marina.v5i2.8154

Rumimpunu, A., Andaki, J. A., \& Manoppo, V. E. N. (2017). Potensi pengembangan usaha budidaya ikan patin (Pangasius sp) di Desa Tatelu Kabupaten Minahasa Utara. Akulturasi: Jurnal IImiah Agrobisnis Perikanan, 5(9), 713-716. https://doi. org/10.35800/akulturasi.5.9.2017.17006

Sari, S. M. (2018, 11 April). Impor dari Vietnam dihentikan, produksi ikan patin meningkat. Bisnis.com. http://m.bisnis.com/amp/ $\mathrm{read} / 20180411 / 99 / 783179 / \mathrm{impor}$-dari-vietnam-dihentikan-produksi-ikan-patin-meningkat

Susanti, S., Lestari, D. A. H., \& Kasymir, E. (2017). Sistem agribisnis ikan patin (Pangasius $s p)$ kelompok budidaya ikan sekar mina di Kecamatan Kota Gajah Lampung Tengah. Jurnal IImu-IImu Agribisnis, 5(2), 116-123. http://dx.doi. org/10.23960/jiia.v5i2.\%25p

Sushanty, D. E., Fauziah, \& Priadi, D. P. (2017). Strategi pengembangan usaha budidaya pembesaran ikan patin (Pangasius sp.) di Kecamatan Gandus Kota Palembang. FishtecH-Jurnal Teknologi Hasil Perikanan, 6(2), 126-133. https://doi. org/10.36706/fishtech.v6i2.5844

Triyanti, R., \& Shafitri, N. (2012). Kajian pemasaran ikan lele (Clarias $s p$ ) dalam mendukung industri perikanan budidaya (Studi kasus di Kabupaten Boyolali, Jawa Tengah). Jurnal Sosial Ekonomi Kelautan dan Perikanan, 7(2), 177-191. http:// dx.doi.org/10.15578/jsekp.v7i2.5684

Utami, H. (2019). Analisis kelayakan dan strategi pengembangan usaha pembesaran ikan patin dalam meningkatkan kesejahteraan masyarakat desa Kota Karang Kecamatan Kumpeh Ulu Kabupaten Muaro Jambi [Skripsi, Universitas Islam Negeri Sulthan Thaha Saifuddin Jambi]. UIN Sulthan Thaha Saifuddin Repository. http:// repository.uinjambi.ac.id/2906/
Widodo, P., Akmal., \& Syafrudin. (2010). Budidaya ikan patin (Pangasius hypophthalmus) pada lahan marjinal di Kabupaten Pulau Pisang di Provinsi Kalimantan Tengah. Prosiding Forum Inovasi Teknologi Akuakultur 2010, 49-60. Pusat Penelitian dan Pengembangan Perikanan Budidaya, Badan Penelitian dan Pengembangan Kelautan dan Perikanan.

Wijaya, B. P. Y., \& Rachmawati, R. (2017). Pengembangan kegiatan perikanan dan peran kelembagaan masyarakat di kawasan minapolitan Kabupaten Gresik. Jurnal Bumi Indonesia, 6(3), 1-10. http://lib.geo.ugm.ac.id/ojs/index.php/jbi/article/ view/770

Wiramiharja, Y. (2017). Analisis keberlanjutan budidaya ikan patin (Pangasius hypophthalmus) dalam pengembangan kawasan minapolitan di Kecamatan Kumpeh Ulu Kabupaten Muaro Jambi [Tesis, Program Studi Magister IImu Kelautan, Bidang Minat Manajemen Perikanan, Universitas Terbuka]. Universitas Terbuka Repository. http:// repository.ut.ac.id/7602/

Yulisti, M., \& Triyanti, R. (2012). Peran kelembagaan dalam mendukung program minapolitan budidaya di Kabupaten Sleman, D. I. Yogyakarta. Buletin IImiah Marina Sosial Ekonomi Kelautan dan Perikanan, 7(1), 27-33. http://dx.doi. org/10.15578/marina.v7i1.4595

Zulkifli. (2019, 4 April). Sehari hasilkan 60 ton ikan patin, Dinas Perikanan Provinsi Jambi kesulitan pengolahan dan pemasaran. TribunJambi. com. https://jambi.tribunnews.com/2019/04/04/ sehari-hasilkan-60-ton-ikan-patin-dinas-perikanan-provinsi-jambi-kesulitan-pengolahan-dan-pemasaran 